\title{
Effect of Soil Amendments Application on Juice Quality and Sugar Yields of Sugar Beet Grown under Saline Soil Conditions
}

\author{
Mohsen A. Gameh ${ }^{1}$, Ramadan E. Knany ${ }^{2}$, Yahya U. Drwesh ${ }^{3}$, \\ Fekry M. Ismaeil ${ }^{3}$, Salah F. Abou-Elwafa ${ }^{4,5}$, \\ ${ }^{1}$ Department of Soils and Water, Faculty of Agriculture, Assiut \\ University, Egypt. \\ ${ }^{2}$ Soils, water and Environment Research. Institute. Agricultural \\ Research Center, Giza, Egypt. \\ ${ }^{3}$ Delta Sugar Company, El-Hamool, Kafr El-Sheikh, Egypt. \\ ${ }^{4}$ Faculty of Sugar and Integrated Industries Technology, Assiut \\ University, Egypt. \\ ${ }^{5}$ Agronomy Department, Faculty of Agriculture, Assiut University, \\ Egypt.
}

\begin{abstract}
Soil salinity adversely affects quality parameters of sugar beet juice leading to a reduction in recoverable sugar yield. Improving the physical and chemical properties of salt affected soils is essential for sustainable cultivation and production of sugar beet in Egypt. A field experiment was carried out at the Delta Sugar Company to evaluate soil amendments, i.e., Phosphogypsium (PG), Desaline, humic acid and treated filter cake and molasses application on roots quality and sugar yield of sugar beet. Application of molasses at a rate of $50 \mathrm{~L} / \mathrm{fed}$. significantly increased sugar content $(\mathrm{Pol} \%)$ only in the first growing season, while soil amendments do not have any significant in sugar content increment and the highest sugar content was produced from plants in the control treatment. Application of soil amendments in particular 1 ton/fed. of treated filter cake significantly reduced $\mathrm{Na} \%, \mathrm{~K} \%$ and $\alpha$-amino- $\mathrm{N}$ in root juice in both growing seasons. Soil amendments application significantly increased sugar beet juice quality, theoretical sugar yield (TSY) and recoverable sugar yield (RSY) in both growing seasons. The highest value of quality index was produced from the application of 1 ton/fed. of treated filter cake. The application of either treated filter cake or $50 \mathrm{~L} / \mathrm{fed}$. of molasses significantly enhances both theoretical and recoverable sugar yields. The effect of soil amendments and molasses application on sugar loss yield was barely significant, and varietal and environmental dependent.
\end{abstract}


Keywords: Sugar beet; Salinity; Juice quality; Sugar yield; Sugar loss.

\section{Introduction}

The harvested area of sugar beet, the first sugar crop in Egypt, exceeds 600,000 feddans (FAO 2019); www.fao.org). The main advantages that made sugar beet, one of the most salt tolerant crops (Kaffka and Kurt 2004), the first sugar crop in Egypt in a short period is its ability to grow effectively and produce a high sugar content in a short growing season in the newly reclaimed soils which are mostly characterized as saline soils (Abo-Elwafa et al. 2006; Abou-Elwafa 2010; Abo-Elwafa et al. 2013). At least $20 \%$ of the world's irrigated land is salt affected, from which $60 \%$ are sodic (Qadir et al. 2006; Pessarakli 2010). In Egypt, salt affected soils represent $9.1 \%$ of the total area and $30 \%$ from the cultivated area (www.fao.org).

Sugar beet quality (sucrose, purity, sugar recovery \%) has also been found to decrease with an increase in salts concentration (AbdelMawly and Zanouly 2004; Almodares and Sharif 2005; Dadkhah and Grrifiths 2006; Khorshid and Rajbi 2014; Wu et al. 2015). Sodium uptake by sugar beet increased impurities in root juice (Eisa and Ali 2005; Eisa et al. 2012) thereby decreases its quality. Total soluble solids (TSS) in beet root juice have been reported to increase significantly with the concentration of salts (Khalil et al. 2001; Zaki et al. 2012; Salami and Saadat 2013). Similarly, Zaki et al. (2014) found that sucrose content, juice purity, sugar recovery and sugar yield in sugar beet decreased with increasing salinity level except sucrose and TSS as salinity increased from control to 5000 ppm during that study. Therefore, improving the physical and chemical properties of salt affected soils in Egypt is essential for sustainable cultivation and production of sugar beet in Egypt (Abdel-Fattah 2012). Remediation of soil salinity could be mediated through the application of three successful, low cost and effective amendment approaches that have been worldwide implemented, i.e., i) chemical agents including calcium compounds, ii) sulfur compounds, and iii) organic matter (Cha-um and Kirdmanee 2011; Amer and El-Ramady 2015). Gypsum 
application improves growth of fodder beet in saline- sodic soils and improves the physical-chemical properties of the soil (Ahmed et al. 2015). The application of humic acid substances improves the physical-chemical properties of the soil including aggregation, aeration, permeability, water holding capacity and micronutrient availability (Tan 2003). Besides, foliar application of humic acid significantly improved sucrose $\%$, extractable sugar $\%$, purity, sugar loss to molasses and root and sugar yields in sugar beet (ElHassanin et al. 2016). Application of sugar beet molasses, the residual syrup from sugar beet processing, mitigates the adverse effects of soil salinity (El-Tokhy et al. 2019).

Filter cake, a residue from the treatment of sugar beet juice by filtration, is a rich source of phosphorus and organic matter and contains a high moisture content and has been widely used as a complete or partial substitute for mineral fertilizers in crop plants (Fravet et al. 2010; Santos et al. 2011; Ossom and Rhykerd 2007; Ossom 2010; Abo-Baker Basha 2011; Ossom and Dlamini 2012; Utami et al. 2012; Santana et al. 2012). In Egypt, more than 170,000 tons of filter cake are annually produced from beet sugar factories, causing severe environment pollution problems. Therefore, it is of immense importance to find an approach for treatment of filter cake to utilize it as a natural source for soil amendment and fertility. Filter cake is utilized as fertilizer in several countries, including Brazil, India, Australia, Cuba, Pakistan, Taiwan, South Africa, and Argentina (de Mello Prado 2013). Application of filter cake, enriched by rock phosphate in the presence or absence of a biofertilizer, in organic onion culture resulted in improved plant nutrition, growth and crop production, in addition to better export quality (Abo-Baker Basha 2011). However, the high $\mathrm{pH}$ value of Egyptian soils excluded the possibility of using filter cake as a fertilizer or soil acidity neutralizer. Therefore, improving the chemical properties of filter cake is a perquisite for its application as soil amendment or as a fertilizer.

The current study was conducted to evaluate the effect of filter cake treated with sulphoric and phosphoric acids and some other 
soil amendments and molasses application on root quality and sugar yield of sugar beet.

\section{Material and methods}

\subsection{Plant material and field experiment}

A field experiment was carried out at the Delta Sugar Company research farm, El-Hamool, Kafr El- Sheikh, Egypt during the two successive growing seasons 2017/2018 and 2018/2019. The sugar beet cultivars Top and Bleno was used in the first and second growing seasons, respectively. Plants were grown on October 22, 2017 and 2018 and harvested on May 15, 2018 and 2019 in the first and second growing seasons, respectively. Seeds were hand sown at $15-20 \mathrm{~cm}$ spaces in a $15 \mathrm{~m}^{2}$ plot consists of 5 rows of $5 \mathrm{~m}$ length, with a distance of $60 \mathrm{~cm}$ between rows. Recommended fertilization and cultural practices were performed according to locally recommended practices for sugar beet production in the area of the study. The main soil properties $(0-20 \mathrm{~cm}$ depth) are described in Table 1. Analysis of the physical and chemical properties of the soil was performed according to Bao (2005).

\subsection{Soil amendments and filter cake treatment}

Four soil amendments, i.e., Phosphogypsium (PG) which is a byproduct of the processing of phosphate rock in plants producing phosphate fertilizers such as superphosphate and phosphoric acid, Desal which is a desalination commercial product, humic acid and treated filter cake. To convert the filter cake (lime cake) from deleterious material to useful material, the filter cake produced from Delta Sugar Company stored from the previous years was treated with a mixture of sulphoric and phosphoric acids (1.5:1) $(18+12$ $\mathrm{cm}^{3} / 100 \mathrm{~g}$ ). The final product contains a mixture of gypsum and monocalcium phosphate beside a portion of calcium carbonate. All four types of soil amendments were added to the soil surface before sowing. 
Table 1: Basic physical and chemical properties of experimental soil.

\begin{tabular}{|c|c|c|}
\hline Parameters & $2017 / 2018$ & $2018 / 2019$ \\
\hline Silt \% & 23.6 & 24.7 \\
\hline Sand \% & 29.1 & 28.3 \\
\hline Clay \% & 47.3 & 47.0 \\
\hline Texture grade & Clayey loam & Clayey loam \\
\hline $\mathrm{CaCO}_{3} \%$ & 3.8 & 4.7 \\
\hline pH & 7.97 & 8.20 \\
\hline EC dSm-1 & 8.67 & 7.50 \\
\hline \multicolumn{3}{|c|}{ Soluble cations, meq $\mathrm{L}^{-1}$} \\
\hline $\mathrm{Ca}^{2+}$ & 32.70 & 26.22 \\
\hline $\mathbf{M g}^{2+}$ & 20.35 & 20,75 \\
\hline $\mathrm{Na}^{+}$ & 32,32 & 27.26 \\
\hline $\mathrm{K}^{+}$ & 1.40 & 1.54 \\
\hline \multicolumn{3}{|c|}{ Soluble anions, meq $L^{-1}$} \\
\hline $\mathrm{Cl}^{-}$ & 52.00 & 42.55 \\
\hline $\mathrm{HCO}_{3}^{-}$ & 4.00 & 5.16 \\
\hline $\mathrm{SO}_{4}{ }^{2-}$ & 30.78 & 28.06 \\
\hline \multicolumn{3}{|c|}{ Available nutrients ppm } \\
\hline $\mathbf{N}$ & 30 & 28 \\
\hline $\mathbf{P}$ & 7.5 & 7.6 \\
\hline $\mathbf{K}$ & 366.6 & 460 \\
\hline
\end{tabular}

\subsection{Phenotypic evaluation}

At harvest, a representative root sample from each treatment was collected for quality analysis by measuring sucrose $\%$, sodium $(\mathrm{Na}) \%$, potassium $(\mathrm{K}) \%$ and $\alpha$-amino- $\mathrm{N}$ in root juice using the venma, Automation BV AnalyzerIIG-16-12-99, 9716JP/ Groningen/Holland according to the procedure of Delta Sugar Company, as described by le-Docte (1927) and Brown and lilliland (1964). The results were calculated as $\mathrm{mmol} / 100 \mathrm{~g}$ beet. Quality index, Sucrose losses \%, recoverable sugar\% and recoverable sugar yield was calculated using the following equation according to Reinefeld (1975): 
Quality $\%=$ Pol $\%-0.29+0.343(K+N a)+0.0939(\alpha-$ amino $N) x 100 /$ Pol $\%$

Sucrose losses $\%=0.14(K+N a)+0.25(\alpha-$ amino $N)+0.5$

Recoverable sugar $\%=$ Pol $\%-0.14(K+N a)+0.25(\alpha-$ amino $N)+0.5$

Recoverable sugar yield $=$ Root yield $\times$ Recoverable sugar $\%$

Theoretical sugar yield $=$ Root yield $\times$ Pol $\%$

Sugar loss yield $=$ Root yield $\times$ sugar losses $\%$

\section{Experimental design and Statistical analysis}

Experiments were designed in a four-replicates randomized complete block design (RCBD) in a split plot design. The main plots were assigned to six soil amendment treatments, i.e., control treatment (without amendments), 1 ton/fed. of treated filter cake, 2 tons/fed. of treated filter cake, 1ton/fed. of phosphogypsium (PG), 4 $\mathrm{L} / \mathrm{fed}$. of Desal (desalination), added to the soil surface before sowing and $4 \mathrm{~L} / \mathrm{fed}$. of humic acid added to the soil surface before sowing. The sub-plots were assigned to three molasses treatments, i.e., control treatment (without molasses application), $25 \mathrm{~L} / \mathrm{fed}$. of molasses added to the soil surface before sowing and $50 \mathrm{~L} / \mathrm{fed}$. of molasses added to the soil surface before sowing. The Proc Mixed of SAS package version 9.2 was used to perform analysis of variance (ANOVA), Fisher's least significant difference (LSD), of significantly differed treatments was calculated.

\section{Results and discussion}

\subsection{Soil amendments reduce juice impurities content}

Application of molasses at a rate of $50 \mathrm{~L} / \mathrm{fed}$. significantly increased sugar content (Pol\%) only in the first growing season, while soil amendments do not have any significant in sugar content increment and the highest sugar content was produced from plants in the control treatment (Table 2). The interaction between soil amendments and molasses application on sugar content revealed that the highest values of sugar content were produced from the control treatment in both growing seasons (Table 3 ), which could be ascribed to that partitioning of photoassimilates was in favor of 
increasing sugar content in the control treatment where root yield has been reduced (Data not shown).

Table 2: Significance levels of soil amendments, molasses and their interaction on $\mathrm{Pol} \%, \mathrm{Na} \%, \mathrm{~K} \%$, $\alpha$-amino- $\mathrm{N}$, quality\%, theoretical sugar yield (TSY), recoverable sugar yield (RSY) and sugar loss yield (SLY) in the two growing seasons 2017/2018 and 2018/2019.

\begin{tabular}{|c|c|c|c|c|c|c|c|c|c|}
\hline $\begin{array}{l}\text { Seas } \\
\text { on }\end{array}$ & S.0.V & $\begin{array}{l}\text { Pol } \\
\%\end{array}$ & $\begin{array}{l}\mathrm{Na} \\
\%\end{array}$ & K\% & $\begin{array}{l}\alpha \text {-amino- } \\
N\end{array}$ & Quality\% & TSY & RSY & SLY \\
\hline \multirow{3}{*}{ 종 } & Soil amend. (S) & $* *$ & $* *$ & $* *$ & $* *$ & $* *$ & $* *$ & $* *$ & NS \\
\hline & Molasses (M) & $* *$ & $* *$ & $* *$ & $* *$ & $* *$ & $* *$ & $* *$ & NS \\
\hline & $\mathbf{S} \times \mathbf{M}$ & $* *$ & $* *$ & $* *$ & $* *$ & $* *$ & $* *$ & $* *$ & NS \\
\hline \multirow{3}{*}{ 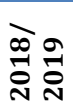 } & Soil amend. (S) & $* *$ & NS & $* *$ & $*$ & $* *$ & $* *$ & $* *$ & $* *$ \\
\hline & Molasses (M) & $* *$ & $* *$ & $* *$ & NS & $* *$ & $* *$ & $* *$ & NS \\
\hline & $\mathbf{S} \times \mathbf{M}$ & $* *$ & $*$ & $* *$ & NS & $* *$ & $* *$ & $* *$ & NS \\
\hline
\end{tabular}

*; exhibited significant effect at $\mathrm{P} \leq 0.05, * *$; exhibited significant effect at $\mathbf{P} \leq \mathbf{0 . 0 1}$, NS; insignificant.

Application of soil amendments in particular 1 ton/fed. of treated filter cake significantly reduced $\mathrm{Na} \%, \mathrm{~K} \%$ and $\alpha$-amino- $\mathrm{N}$ in root juice in both growing seasons, however the reduction was slight (Table 3). The control treatment exhibited the highest values of $\mathrm{Na} \%, \mathrm{~K} \%$ and $\alpha$-amino- $\mathrm{N}$ in the first growing season $(4.61,8.55$ and $2.57 \%$, respectively), while the lowest values $(3.44,7.30$ and $1.34 \%$, respectively) were produced from the application of 1 ton/fed. of treated filter cake. In the second growing season the lowest values of $\mathrm{Na} 5$ and aamino-N (1.86 and 1.34\%), resulted from the application of phosphogypsum, while the lowest $\mathrm{K}$ value $(5.01 \%)$ was recorded for the application of humic acid (Table 3). In addition to variations in ambient environmental cues, variations between the two growing seasons could be attributed to the implementation of two different cultivars in the two growing seasons. The effect of either treated filter cake and phosphogypsum may be due to that the presence of $\mathrm{Ca}^{++}$ions in excess that led to a reduction in the absorption of $\mathrm{Na}^{+}$and $\mathrm{K}^{+}$and therefore affected membrane permeability to control sodium absorption. These results are consistent with previous results reported by Shaheen et al. (2017) and Amer and Hashem (2018) who stated that soil amendments can cause contradictory effects on elements 
140 Mohsen A. Gameh, et al. (2020), Egyptian Sugar Journal, mobilization and phytoavailability depending on the type of elements and amendments. 
Table 3: Effect of soil amendments and molasses application on Pol\%, $\mathrm{Na} \%, \mathrm{~K} \%$ and $\alpha$-amino $\mathrm{N}$ in the two growing seasons 2017/2018 and 2018/2019.

\begin{tabular}{|c|c|c|c|c|c|c|c|c|c|}
\hline \multicolumn{2}{|c|}{ Growing season } & \multicolumn{4}{|c|}{$2017 / 2018$} & \multicolumn{4}{|c|}{$2018 / 2019$} \\
\hline $\begin{array}{c}\text { Soil } \\
\text { amendments }\end{array}$ & Molasses & Pol \% & $\mathrm{Na} \%$ & $\mathbf{K} \%$ & $\alpha$-amino $N$ & Pol \% & $\mathrm{Na} \%$ & $\mathrm{~K} \%$ & $\alpha$-amino $\mathbf{N}$ \\
\hline \multirow[t]{3}{*}{ Control } & Control & $19.73 \mathrm{ab}$ & 4.59ab & 8.50ab & $2.75 a$ & 19.47abc & 2.01ab & 5.18 & 5.18 \\
\hline & 25L Molasses & 20.09 a & 4.57ab & $8.64 a$ & $2.47 b$ & 19.50ab & 2.16ab & 4.98 & 4.98 \\
\hline & 50L Molasses & $19.90 \mathrm{ab}$ & $4.67 a$ & 8.51ab & $2.48 \mathrm{bc}$ & 19.16abc & 1.76abc & 5.23 & 5.98 \\
\hline \multicolumn{2}{|c|}{ Mean } & 19.91a & $4.61 a$ & $8.55 a$ & $2.57 \mathrm{a}$ & $19.38 \mathrm{a}$ & 1.98 & 5.13abc & 5.38ab \\
\hline \multirow{3}{*}{$\begin{array}{l}\text { Filter cake } \\
\text { (1 t/fed.) }\end{array}$} & Control & $18.36 \mathrm{e}$ & 3.51gh & 7.41ghi & $1.87 \mathrm{ef}$ & 18.92 bc & 2.04ab & 5.05 & 5.05 \\
\hline & 25L Molasses & 18.69 cde & $3.68 f g$ & $7.30 \mathrm{hi}$ & $2.15 d$ & $18.22 \mathrm{~d}$ & $1.84 a b$ & 5.37 & 5.37 \\
\hline & 50L Molasses & 18.66 cde & $3.14 i$ & $7.20 \mathrm{i}$ & $1.77 f$ & $18.33 \mathrm{~d}$ & $1.69 \mathrm{bc}$ & 5.08 & 5.08 \\
\hline \multicolumn{2}{|c|}{ Mean } & $18.57 c$ & $3.44 \mathrm{e}$ & $7.30 \mathrm{e}$ & $1.93 d$ & 18.49d & 1.86 & 5.17ab & 5.17ab \\
\hline \multirow{3}{*}{$\begin{array}{l}\text { Filter cake } \\
\text { (2 t/fed.) }\end{array}$} & Control & 18.62 de & 4.52ab & 7.75efg & $2.32 \mathrm{~cd}$ & 19.09 abc & $2.23 a$ & 5.23 & 5.23 \\
\hline & 25L Molasses & 18.54 de & 4.38ad & $8.25 b c$ & $2.40 \mathrm{bc}$ & 18.85 bc & 1.81abc & 4.99 & 4.99 \\
\hline & 50L Molasses & 18.97 cde & $4.09 \mathrm{cf}$ & $7.57 f i$ & $1.75 f$ & $18.77 \mathrm{c}$ & 1.87ab & 4.85 & 4.85 \\
\hline \multicolumn{2}{|c|}{ Mean } & 18.71bc & $4.33 b$ & $7.86 \mathrm{~cd}$ & $2.16 c$ & $18.90 \mathrm{c}$ & 1.97 & $5.02 \mathrm{c}$ & 5.02ab \\
\hline \multirow[t]{3}{*}{ Phosphogypsum } & Control & $18.19 \mathrm{e}$ & $4.08 \mathrm{cf}$ & 7.60fgh & $2.32 \mathrm{~cd}$ & 19.36 abc & 1.99ab & 5.12 & 5.12 \\
\hline & 25L Molasses & 19.33 bed & 3.99def & 7.91def & 1.91ef & 19.15 abc & $1.73 \mathrm{bc}$ & 4.88 & 4.88 \\
\hline & 50L Molasses & 19.47 abc & 4.33ad & 7.77efg & $1.78 f$ & $19.64 \mathrm{a}$ & $1.41 \mathrm{c}$ & 5.27 & 5.27 \\
\hline \multicolumn{2}{|c|}{ Mean } & $19.00 b$ & $4.13 c$ & $7.76 d$ & $2.00 d$ & $19.38 a$ & 1.71 & $5.09 b c$ & $5.09 \mathrm{~b}$ \\
\hline \multirow[t]{3}{*}{ Desal } & Control & 19.46 abc & 4.22be & 7.53ghi & $2.00 \mathrm{e}$ & 19.11 abc & 2.10ab & 5.29 & 5.29 \\
\hline & 25L Molasses & 18.86 cde & 4.46abc & 8.54ab & $2.57 \mathrm{~b}$ & 19.05 abc & 1.99ab & 5.12 & 5.12 \\
\hline & 50L Molasses & 18.91 cde & $4.06 \mathrm{cf}$ & 7.99cde & $2.48 \mathrm{bc}$ & 19.11 abc & 2.13ab & 5.32 & 5.32 \\
\hline \multicolumn{2}{|c|}{ Mean } & $19.08 b$ & $4.25 \mathrm{bc}$ & $8.02 b$ & $2.35 b$ & $19.09 \mathrm{~b}$ & 2.07 & $5.24 a$ & $5.24 a$ \\
\hline \multirow[t]{3}{*}{ Humic acid } & Control & $18.61 \mathrm{de}$ & $3.27 \mathrm{hi}$ & $7.27 \mathrm{hi}$ & $2.42 \mathrm{bc}$ & 19.44 abc & 2.02ab & 5.14 & 5.14 \\
\hline & 25L Molasses & 19.02 cde & 4.00def & 8.38ab & $2.30 \mathrm{~cd}$ & 19.37 abc & 2.06ab & 4.77 & 4.77 \\
\hline & 50L Molasses & 18.94 cde & 3.80efg & $8.20 b c$ & $2.25 \mathrm{~cd}$ & 18.89 bc & 1.76abc & 5.10 & 5.1 \\
\hline \multicolumn{2}{|c|}{ Mean } & 18.86bc & 3.69d & 7.95bc & $2.32 \mathrm{~b}$ & $19.23 b$ & 1.95 & $5.00 \mathrm{c}$ & $5.00 b$ \\
\hline
\end{tabular}


Molasses application significantly decreased $\mathrm{Na}, \mathrm{K}$ and $\alpha$-amino-N contents in sugar beet juice in both growing seasons. These results are in agreement with El-Tokhy et al. (2019) who stated that molasses effects attributed to molasses contain glycine betaine material as a compatible solute in osmotic adjustment of the cytoplasmic compartment. The interaction between soil amendments and molasses application exhibited highly significant effects on $\mathrm{Na}, \mathrm{K}$ and $\alpha$-amino- $\mathrm{N}$ contents in sugar beet juice (Table 2). The lowest values $\mathrm{Na}(3.14 \%), \mathrm{K}(7.2 \%)$ and $\alpha$-amino-N $(1.77 \%)$ in the first growing season and $\mathrm{Na}(1.69 \%)$ in the second growing season were obtained from the application of 1 ton/fed. of treated filter cake in combination with $50 \mathrm{~L}$ molasses/fed., while the highest values were observed in the control treatment.

\subsection{Soil amendments application enhances juice quality and sugar yields}

Soil amendments application significantly increased sugar beet juice quality, theoretical sugar yield (TSY) and recoverable sugar yield (RSY) in both growing seasons (Table 2). The highest value of quality index $(77.44 \%)$ in the first growing season was produced from the application of 1 ton/fed. of treated filter cake, while in the second growing season although the significance of the differences among different treatments in juice quality there is no superior treatment could be identified (Table 4). The interaction between soil amendments and molasses application exhibited significant effects in both growing seasons. Superiority was recorded to the application ion of either phosphogypsum or 2 ton/fed. of treated filter cake in combination with $50 \mathrm{~L} / \mathrm{fed}$. of molasses in the first growing season, while in the second growing season the application of phosphogypsum with $25 \mathrm{~L} / \mathrm{fed}$. of molasses produced the highest juice quality value (Table 4 ).

Data presented in Table 3 showed that the application of either 1 or 2 ton/fed. of treated filter cake produced the significantly highest theoretical sugar yield (4.85 and 5.44 ton/fed.) in both growing seasons. Similarly, the application of molasses at a rate of $50 \mathrm{~L} / \mathrm{fed}$. 
significantly increased theoretical sugar yield in both growing seasons. These results which are consistent with previous results (Rymar' et al. 2003; El-Shazly et al. 2014) could due to the high root yields produced form the application of treated filter cake (Table 4). The interaction between soil amendments and molasses exhibited highly significant effects on theoretical sugar yield in both growing seasons (Table 4). The highest theoretical sugar yields (5.09 and 5.87 ton/fed.) were obtained from the application of 1 ton/fed. of treated filter cake in combination with $25 \mathrm{~L}$ molasses/fed. in the first growing season, while in the second growing season the highest sugar yield was recorded for the application of 1 ton/fed. of treated filter cake without molasses. These results suggest that the application of filter cake is the main determinant factor in enhancing theoretical sugar yield in sugar beet. Besides, the differences between the two growing seasons is mainly due to the implementation of different cultivar in each season, indicating that selection of appropriate cultivars is the most straightforward approach for improving sugar beet productivity. These results are in agreement with Amer (2015).

The highest values of RSY (3.75 and 4.60 ton/fed. in the first and second growing seasons, respectively) were produced from the application of 1 ton/fed. of treated filter cake. The application of 50 $\mathrm{L} /$ fed. of molasses resulted in the highest RSY (3.32 and 4.31 ton/fed.) in the first and second growing seasons, respectively (Table 4). The application of $25 \mathrm{~L} / \mathrm{fed}$. of molasses in combination with the application of 1 ton/fed. of treated filter cake produced the highest RSY (3.93 ton/fed.) in the first growing season. Meanwhile, in the second growing season the highest RSY (4.97 ton/fed.) was produced from the application of 1 ton/fed. of treated filter cake without any application of molasses (Table 4).

The application of soil amendments exhibited a significant effect on sugar loss yield (SLY) only in the second growing season (Table 2). Meanwhile, molasses application has no significant effect on sugar losses in either growing season. Although the significance of the difference among soil amendments application observed in the 
142 Mohsen A. Gameh, et al. (2020), Egyptian Sugar Journal,

second growing season, these differences have not been in favor of any particular treatment. However, the lowest value of SLY ( 0.65 ton/fed.) was recorded for the control treatment, and the highest value ( 0.83 ton/ fed.) was recorded for the application of 1 ton/fed. of treated filter cake (Table 4). These results could be due that the application of treated filter cake enhances root yield which in turn lead to an increase all root yield associated juice parameters. No significant effects of the interaction between soil amendments and molasses application on SLY in both growing se asons (Table 4). 
Table 3: Effect of soil amendments and molasses application on $\mathrm{Pol} \%, \mathrm{Na} \%, \mathrm{~K} \%$ and $\alpha$-amino $\mathrm{N}$ in the two growing seasons 2017/2018 and 2018/2019.

\begin{tabular}{|c|c|c|c|c|c|c|c|c|c|}
\hline \multicolumn{2}{|c|}{ Growing season } & \multicolumn{4}{|c|}{$2017 / 2018$} & \multicolumn{4}{|c|}{$2018 / 2019$} \\
\hline $\begin{array}{c}\text { Soil } \\
\text { amendments }\end{array}$ & Molasses & Pol \% & $\mathrm{Na} \%$ & $\mathrm{~K} \%$ & $\alpha$-amino $\mathbf{N}$ & Pol \% & $\mathrm{Na} \%$ & $\mathrm{~K} \%$ & $\alpha$-amino $\mathbf{N}$ \\
\hline \multirow[t]{3}{*}{ Control } & Control & $19.73 \mathrm{ab}$ & 4.59ab & 8.50ab & $2.75 a$ & 19.47abc & 2.01ab & 5.18 & 5.18 \\
\hline & 25L Molasses & 20.09 a & 4.57ab & $8.64 a$ & $2.47 b$ & 19.50ab & 2.16ab & 4.98 & 4.98 \\
\hline & 50L Molasses & $19.90 \mathrm{ab}$ & $4.67 a$ & 8.51ab & $2.48 \mathrm{bc}$ & 19.16abc & 1.76abc & 5.23 & 5.98 \\
\hline \multicolumn{2}{|r|}{ Mean } & 19.91a & $4.61 a$ & $8.55 a$ & $2.57 a$ & 19.38a & 1.98 & 5.13abc & 5.38ab \\
\hline \multirow{3}{*}{$\begin{array}{l}\text { Filter cake } \\
\text { (1 t/fed.) }\end{array}$} & Control & $18.36 \mathrm{e}$ & 3.51gh & 7.41ghi & $1.87 \mathrm{ef}$ & 18.92 bc & 2.04ab & 5.05 & 5.05 \\
\hline & 25L Molasses & 18.69 cde & $3.68 f g$ & 7.30hi & $2.15 d$ & $18.22 \mathrm{~d}$ & 1.84ab & 5.37 & 5.37 \\
\hline & 50L Molasses & 18.66 cde & $3.14 i$ & $7.20 \mathrm{i}$ & $1.77 f$ & $18.33 \mathrm{~d}$ & $1.69 \mathrm{bc}$ & 5.08 & 5.08 \\
\hline \multicolumn{2}{|r|}{ Mean } & $18.57 \mathrm{c}$ & $3.44 \mathrm{e}$ & $7.30 \mathrm{e}$ & 1.93d & 18.49d & 1.86 & 5.17ab & $5.17 \mathrm{ab}$ \\
\hline \multirow{3}{*}{$\begin{array}{l}\text { Filter cake } \\
\text { (2 t/fed.) }\end{array}$} & Control & 18.62 de & 4.52ab & 7.75efg & $2.32 \mathrm{~cd}$ & 19.09 abc & $2.23 a$ & 5.23 & 5.23 \\
\hline & 25L Molasses & 18.54 de & 4.38ad & $8.25 b c$ & $2.40 \mathrm{bc}$ & 18.85 bc & 1.81abc & 4.99 & 4.99 \\
\hline & 50L Molasses & 18.97 cde & $4.09 \mathrm{cf}$ & 7.57fi & $1.75 f$ & $18.77 \mathrm{c}$ & 1.87ab & 4.85 & 4.85 \\
\hline \multicolumn{2}{|r|}{ Mean } & 18.71bc & $4.33 b$ & $7.86 \mathrm{~cd}$ & $2.16 \mathrm{c}$ & $18.90 \mathrm{c}$ & 1.97 & $5.02 c$ & 5.02ab \\
\hline \multirow{3}{*}{$\begin{array}{l}\text { Phosphogyps } \\
\text { um }\end{array}$} & \begin{tabular}{|c|} 
Control \\
\end{tabular} & 18.19 e & $4.08 \mathrm{cf}$ & 7.60fgh & $2.32 \mathrm{~cd}$ & 19.36 abc & 1.99ab & 5.12 & 5.12 \\
\hline & 25L Molasses & $19.33 \mathrm{bcd}$ & 3.99def & 7.91def & 1.91ef & 19.15 abc & $1.73 \mathrm{bc}$ & 4.88 & 4.88 \\
\hline & 50L Molasses & 19.47 abc & 4.33ad & 7.77efg & $1.78 f$ & 19.64 a & $1.41 \mathrm{c}$ & 5.27 & 5.27 \\
\hline \multicolumn{2}{|r|}{ Mean } & 19.00b & $4.13 c$ & 7.76d & 2.00d & $19.38 \mathrm{a}$ & 1.71 & $5.09 b c$ & $5.09 b$ \\
\hline \multirow[t]{3}{*}{ Desal } & Control & 19.46 abc & 4.22be & 7.53ghi & $2.00 \mathrm{e}$ & 19.11 abc & 2.10ab & 5.29 & 5.29 \\
\hline & 25L Molasses & 18.86 cde & 4.46abc & 8.54ab & $2.57 b$ & 19.05 abc & 1.99ab & 5.12 & 5.12 \\
\hline & 50L Molasses & 18.91 cde & $4.06 \mathrm{cf}$ & 7.99cde & $2.48 \mathrm{bc}$ & 19.11 abc & 2.13ab & 5.32 & 5.32 \\
\hline \multicolumn{2}{|r|}{ Mean } & $19.08 b$ & $4.25 b c$ & $8.02 b$ & $2.35 b$ & $19.09 \mathrm{~b}$ & 2.07 & $5.24 a$ & $5.24 a$ \\
\hline \multirow[t]{3}{*}{ Humic acid } & Control & $18.61 \mathrm{de}$ & 3.27hi & 7.27hi & $2.42 \mathrm{bc}$ & 19.44 abc & 2.02ab & 5.14 & 5.14 \\
\hline & 25L Molasses & 19.02 cde & 4.00def & 8.38ab & $2.30 \mathrm{~cd}$ & 19.37 abc & 2.06ab & 4.77 & 4.77 \\
\hline & 50L Molasses & 18.94 cde & $3.80 \mathrm{efg}$ & 8.20bc & $2.25 \mathrm{~cd}$ & 18.89 bc & 1.76abc & 5.10 & 5.1 \\
\hline \multicolumn{2}{|r|}{ Mean } & 18.86bc & $3.69 d$ & $7.95 b c$ & $2.32 \mathrm{~b}$ & $19.23 b$ & 1.95 & $5.00 \mathrm{c}$ & $5.00 \mathrm{~b}$ \\
\hline
\end{tabular}



Molasses application significantly decreased $\mathrm{Na}, \mathrm{K}$ and $\alpha$-amino-N contents in sugar beet juice in both growing seasons. These results are in agreement with $\boldsymbol{E l - T o k h y}$ et al. (2019) who stated that molasses effects attributed to molasses contain glycine betaine material as a compatible solute in osmotic adjustment of the cytoplasmic compartment. The interaction between soil amendments and molasses application exhibited highly significant effects on $\mathrm{Na}, \mathrm{K}$ and $\alpha$-amino-N contents in sugar beet juice (Table 2). The lowest values $\mathrm{Na}(3.14 \%), \mathrm{K}(7.2 \%)$ and $\alpha$-amino-N $(1.77 \%)$ in the first growing season and $\mathrm{Na}(1.69 \%)$ in the second growing season were obtained from the application of 1 ton/fed. of treated filter cake in combination with $50 \mathrm{~L}$ molasses/fed., while the highest values were observed in the control treatment.

\subsection{Soil amendments application enhances juice quality and sugar yields}

Soil amendments application significantly increased sugar beet juice quality, theoretical sugar yield (TSY) and recoverable sugar yield (RSY) in both growing seasons (Table 2). The highest value of quality index $(77.44 \%)$ in the first growing season was produced from the application of 1 ton/fed. of treated filter cake, while in the second growing season although the significance of the differences among different treatments in juice quality there is no superior treatment could be identified (Table 4). The interaction between soil amendments and molasses application exhibited significant effects in both growing seasons. Superiority was recorded to the application ion of either phosphogypsum or 2 ton/fed. of treated filter cake in combination with $50 \mathrm{~L} / \mathrm{fed}$. of molasses in the first growing season, while in the second growing season the application of phosphogypsum with $25 \mathrm{~L} / \mathrm{fed}$. of molasses produced the highest juice quality value (Table 4).

Data presented in Table 3 showed that the application of either 1 or 2 ton/fed. of treated filter cake produced the significantly highest theoretical sugar yield (4.85 and 5.44 ton/fed.) in both growing seasons. Similarly, the application of molasses at a rate of $50 \mathrm{~L} /$ fed. 
significantly increased theoretical sugar yield in both growing seasons. These results which are consistent with previous results (Rymar' et al. 2003; El-Shazly et al. 2014) could due to the high root yields produced form the application of treated filter cake (Table 4). The interaction between soil amendments and molasses exhibited highly significant effects on theoretical sugar yield in both growing seasons (Table 4). The highest theoretical sugar yields (5.09 and 5.87 ton/fed.) were obtained from the application of 1 ton/fed. of treated filter cake in combination with $25 \mathrm{~L}$ molasses/fed. in the first growing season, while in the second growing season the highest sugar yield was recorded for the application of 1 ton/fed. of treated filter cake without molasses. These results suggest that the application of filter cake is the main determinant factor in enhancing theoretical sugar yield in sugar beet. Besides, the differences between the two growing seasons is mainly due to the implementation of different cultivar in each season, indicating that selection of appropriate cultivars is the most straightforward approach for improving sugar beet productivity. These results are in agreement with Amer (2015).

The highest values of RSY (3.75 and 4.60 ton/fed. in the first and second growing seasons, respectively) were produced from the application of 1 ton/fed. of treated filter cake. The application of 50 $\mathrm{L} / \mathrm{fed}$. of molasses resulted in the highest RSY (3.32 and 4.31 ton/fed.) in the first and second growing seasons, respectively (Table 4). The application of $25 \mathrm{~L} / \mathrm{fed}$. of molasses in combination with the application of $1 \mathrm{ton} / \mathrm{fed}$. of treated filter cake produced the highest RSY (3.93 ton/fed.) in the first growing season. Meanwhile, in the second growing season the highest RSY (4.97 ton/fed.) was produced from the application of 1 ton/fed. of treated filter cake without any application of molasses (Table 4).

The application of soil amendments exhibited a significant effect on sugar loss yield (SLY) only in the second growing season (Table 2). Meanwhile, molasses application has no significant effect on sugar losses in either growing season. Although the significance of the difference among soil amendments application observed in the second growing season, these differences have not been in favor of 
any particular treatment. However, the lowest value of SLY (0.65 ton/fed.) was recorded for the control treatment, and the highest value $(0.83$ ton/ fed.) was recorded for the application of 1 ton/fed. of treated filter cake (Table 4). These results could be due that the application of treated filter cake enhances root yield which in turn lead to an increase all root yield associated juice parameters. No significant effects of the interaction between soil amendments and molasses application on SLY in both growing seasons (Table 4). 

Table 4: Effect of soil amendments and molasses application on quality \%, theoretical sugar yield (TSY), recoverable sugar yield (RSY) and sugar loss yield (SLY) in the two growing seasons 2017/2018 and 2018/2019.

\begin{tabular}{|c|c|c|c|c|c|c|c|c|c|}
\hline \multicolumn{2}{|c|}{ Growing season } & \multicolumn{4}{|c|}{$2017 / 2018$} & \multicolumn{4}{|c|}{$2018 / 2019$} \\
\hline $\begin{array}{c}\text { Soil } \\
\text { amendments }\end{array}$ & Molasses & Quality\% & $\begin{array}{c}\text { TSY } \\
\text { (ton/fed.) }\end{array}$ & $\begin{array}{c}\text { RSY } \\
\text { (ton/fed.) }\end{array}$ & $\begin{array}{c}\text { SLY } \\
\text { (ton/fed.) }\end{array}$ & Quality\% & $\begin{array}{c}\text { TSY } \\
\text { (ton/fed.) }\end{array}$ & $\begin{array}{c}\text { RSY } \\
\text { (ton/fed.) }\end{array}$ & $\begin{array}{c}\text { SLY } \\
\text { (ton/fed.) }\end{array}$ \\
\hline \multirow[t]{3}{*}{ Control } & Control & $74.32 \mathrm{~g}$ & $3.57 i$ & $2.66 \mathrm{i}$ & 0.91 & 84.90cde & $4.22 \mathrm{~g}$ & $3.59 \mathrm{~g}$ & 0.64 \\
\hline & 25L Molasses & 75.47ef & $4.08 \mathrm{~g}$ & $3.08 \mathrm{~g}$ & 1.00 & $85.25 \mathrm{bcd}$ & $4.49 f$ & 3.83f & 0.66 \\
\hline & 50L Molasses & $74.32 \mathrm{~g}$ & 3.86h & $2.87 \mathrm{~h}$ & 0.99 & $85.70 b$ & $4.56 f$ & 3.91f & 0.65 \\
\hline \multicolumn{2}{|c|}{ Mean } & 74.70d & $3.84 c$ & $2.87 \mathrm{e}$ & 0.97 & $85.28 \mathrm{a}$ & 4.42f & $3.78 f$ & $0.65 \mathrm{c}$ \\
\hline \multirow{2}{*}{$\begin{array}{l}\text { Filter cake } \\
\text { (1 t/fed.) }\end{array}$} & Control & 77.22abc & 4.78bc & $3.69 \mathrm{~b}$ & 1.09 & 84.73def & $5.87 a$ & $4.97 a$ & 0.90 \\
\hline & 50L Molasses & 77.72a & $4.68 \mathrm{bc}$ & $3.64 \mathrm{bc}$ & 1.04 & 85.15b-e & $5.29 \mathrm{bc}$ & $4.50 \mathrm{~b}$ & 0.79 \\
\hline \multicolumn{2}{|c|}{ Mean } & 77.44a & $4.85 \mathrm{a}$ & $3.75 a$ & 1.10 & $84.66 b$ & $5.44 a$ & $4.60 \mathrm{a}$ & $0.83 a$ \\
\hline \multirow{3}{*}{$\begin{array}{l}\text { Filter cake } \\
(2 \text { t/fed.) }\end{array}$} & Control & 75.52ef & $4.82 \mathrm{~b}$ & $3.64 \mathrm{bc}$ & 1.11 & 84.20fg & 5.01de & 4.22de & 0.79 \\
\hline & 25L Molasses & 76.10de & 4.61c & 3.51d & 1.10 & $85.40 b c$ & 5.07de & $4.32 \mathrm{~cd}$ & 0.74 \\
\hline & 50L Molasses & 77.10a-d & 4.78bc & $3.69 \mathrm{~b}$ & 1.09 & $85.48 b c$ & 5.33ab & $4.56 \mathrm{~b}$ & 0.77 \\
\hline \multicolumn{2}{|c|}{ Mean } & $76.24 b$ & $4.74 a$ & 3.61b & 1.10 & 85.03ab & $5.14 b$ & $4.37 b$ & 0.77ab \\
\hline \multirow{2}{*}{$\begin{array}{l}\text { Phosphogypsu } \\
\text { m }\end{array}$} & Control & $74.80 \mathrm{fg}$ & $3.80 \mathrm{~h}$ & $2.84 \mathrm{~h}$ & 0.96 & 85.12b-e & $4.59 \mathrm{f}$ & $3.90 \mathrm{f}$ & 0.68 \\
\hline & 25L Molasses & 76.32b-e & $3.34 \mathrm{j}$ & $2.55 \mathrm{j}$ & 0.79 & $86.20 a$ & $4.88 \mathrm{e}$ & 4.21de & 0.67 \\
\hline \multicolumn{2}{|c|}{ Mean } & $76.11 \mathrm{~b}$ & 3.62d & $2.75 f$ & 0.87 & $85.66 a$ & 4.87d & 4.16d & 0.70bc \\
\hline \multirow[t]{3}{*}{ Desal } & Control & 75.78ef & $4.27 \mathrm{ef}$ & $3.23 f$ & 1.04 & 84.67def & $5.11 \mathrm{~cd}$ & $4.33 \mathrm{~cd}$ & 0.78 \\
\hline & 25L Molasses & 75.40ef & 4.40de & 3.32ef & 1.08 & 85.00cde & 4.94de & $4.20 \mathrm{e}$ & 0.74 \\
\hline & 50L Molasses & 75.37ef & 4.41de & 3.32ef & 1.09 & 84.53efg & $5.13 \mathrm{~cd}$ & $4.33 \mathrm{~cd}$ & 0.79 \\
\hline \multicolumn{2}{|c|}{ Mean } & $75.52 \mathrm{c}$ & $4.36 \mathrm{~b}$ & 3.29d & 1.07 & 84.73b & $5.06 \mathrm{c}$ & $4.29 c$ & 0.77ab \\
\hline \multirow[t]{3}{*}{ Humic acid } & Control & 77.10a-d & 4.18fg & $3.22 \mathrm{f}$ & 0.96 & 85.10b-e & 4.61f & $3.91 f$ & 0.69 \\
\hline & 25L Molasses & 75.73ef & $4.47 d$ & $3.38 \mathrm{e}$ & 1.08 & 85.73b & $4.55 f$ & $3.90 \mathrm{f}$ & 0.65 \\
\hline & 50L Molasses & 76.17cde & $4.67 \mathrm{bc}$ & $3.56 \mathrm{~cd}$ & 1.13 & 85.22bcd & 4.91e & $4.18 \mathrm{e}$ & 0.72 \\
\hline \multicolumn{2}{|c|}{ Mean } & $\begin{array}{l}76.33 b \\
\end{array}$ & $4.44 b$ & $3.39 \mathrm{c}$ & 1.06 & 85.35a & $4.69 \mathrm{e}$ & $4.00 \mathrm{f}$ & $0.69 b c$ \\
\hline
\end{tabular}





\section{References}

Abdel-Fattah, M. K. (2012). Role of gypsum and compost in reclaiming saline-sodic soils. J. of Agric. and Veterinary Sci., 1 (3): 30-38.

Abo-Baker Basha A. A. (2011). Improving filter mud cake with rock phosphate and biofertilizers for exporting organic onion production in newly cultivated land at south valley area. Australian Journal of Basic and Applied Sciences, vol. 5, no. 8, pp. 1354-1361.

Abo-Elwafa, S.F., Abdel-Rahim, H.M., Abou-Salama, A.M., Teama, E.A. (2006). Sugar beet floral induction and fertility: Effect of vernalization and day-length extension. Sugar Tech, 8, 281-287.

Abo-Elwafa, S.F., Abdel-Rahim, H.M., Abou-Salama, A.M., Teama, E.A. (2013). Effect of root age and day-length extension on sugar beet floral induction and fertility. World Journal of Agricultural Research, 1(5), 90-95.

Abou-Elwafa, S. (2010). Novel Genetic Factors Affecting Bolting and Floral Transition Control in Beta vulgaris (Doctoral dissertation). Faculty of Agricultural and Nutritional Sciences, Christian-Albrechts-University of Kiel.

Abdel-Mawly, S.E and I. Zanouly (2004). Response of sugar beet (Beta vulgaris, L.) to potassium application and with saline water irrigation. Ass. Univ. Bull. Environ. Res., 7 (1) 76: 665-679.

Ahmed, K. G, Qadir, A.R, Jami, M.Q. Nawaz, A. Rehim, K. Jabran and M. Hussain (2015). Gypsum and farm manure application with chiseling improve soil properties and performance of fodder beet under saline-sodic conditions. Int. J. Agric. Biol., 17: $1225-1230$.

Almodares, A and M. E. Sharif (2007). Effect of irrigation qualities on biomass and sugar content of sugar beet and sweet sorghum cultivars. J. Environ. Biol., 28(2): 213-218. 
Amer, M. M. (2015). effect of gypsum, sugar factory lime and molasses on some soil proprieties and productivity of sugar beet(beta vulgaris L.) grown on saline-sodic soils of Nile north Delta. J. Soil Sci. and Agric. Eng., Mansoura Univ., Vol. 6(3):pp 120.

Amer, M.M. and El-Ramady, H. R. (2015). Alleviation soil salinity and sodicityhazard using some bio-chemical Amendments 150 135. for production of canola (Brassica Napus L.) in North Delta region. J. Soil Sci. and Agric. Eng. Mansoura Univ.pp120-

Amer, M. M. and. M. Hashem (2018). Impact of some soil amendments on properties and productivity of salt affected soils at Kafr El-Sheikh governorate, Egypt. J. Soil Sci., Vol. 58, No. 2, pp. $177-191$.

Bao, S.D. (2005). Soil and Agricultural Chemistry Analysis. Agriculture Press, Beijing, China.

Brown, J.D and O. Lilliland (1964). Rapid determination of potassium and sodium in plant material and soil in extracts by flamephotometry. Proc. Amer. Soc. Hort.Sci. 48: 341-346.

Cha-um, S. and Kirdmanee, C. (2011). Remediation of saltaffected soil by the addition of organic matter: an investigation into improving glutinous rice productivity. Sci. Agric. (Piracicaba, Braz.), 68 (4): 406- 410.

Dadkhah, A. R. and R. H. Grrifiths (2006). The effect of salinity on growth, inorganic ions and dry matter partitioning in sugar beet cultivars. J. Agric. Sci. Technol., 8: 199-210.

de Mello Prado R., Caione G., Campos C. N. S. (2013). Filter Cake and Vinasse as Fertilizers Contributing to Conservation Agriculture. Applied and Environmental Soil Science, 1-8.

Eisa, S. S. and S. H. Ali (2005). Biochemical, Physiological and Morphological responses of sugar beet to salinization. J. Agric. Sci. Mansoura, Univ., 30(9): 2531-5242. 
Eisa, S. S., A. M. Ibrahim, H. S. Khafaga and S.A Shehata (2012). Alleviation of Adverse Effects of Salt Stress on Sugar Beet by Pre-Sowing Seed Treatments. J. App. Sci. Res., 8 (2): 799-806.

El-Hassanin, A.S., S.M.R. Moustafa, N. Shafika, A.M. Khalifa and M. Ibrahim (2016). Effect of foliar application with humic acid substances under nitrogen fertilization levels on quality and yields of sugar beet plant. J. Curr. Microbiol. App. Sci 5(11):668680.

151 azly, M. A.; R. A. El-Dissoky and M. S. Awaad (2014). Etfect of soil amendments and nitrogen fertilizer sources on sugar beet productivity grown under salt affected soil conditions J. Soil Sci. and Agric. Eng., Mansoura Univ., Vol. 5 (2): 267 - 278.

El-Tokhy, F.K., Tantawy, A.S., El-Shinawy, M.Z. and Abou- ElHadid (2019). Effect of sugar beet molasses and Fe-EDHHA on tomato plants grown under saline water irrigation condition Arab Univ. J Agric. Sci. (aujas), Ain Shams Univ., Cairo, Egypt,26(9D), 2297-2310.

Fravet P. R. F., R. A. B. Soares, R. M. Q. Lana, A. M. Q. Lana, and G. H. Korndörfer (2011). Efeito de doses de torta de filtro e modo de aplicação sobre a produtividade e qualidade tecnológica da soqueira de cana-de-açúcar," Ciência e Agrotecnologia, vol. 34, no. 3, pp. 618-624.

Kaffka, S. and Kurt, H. (2004). The effects of saline soil, irrigation, and seed treatments on Sugar beet. J. Sugar Beet Res., 41(3):61-72.

Khalil, S. M., S. N. Mostafa and Z. R. Mostafa (2001). Influence of potassium fertilizer and soil salinity on chemical composition of sugar beet root. Minufiya J. Agric. Res., 26 (3): 583-594.

Khorshid, A and A. Rajabi (2014). Investigation on quantity and quality characters of sugar beet advanced breeding populations in drought and salinity stress and non-stress conditions.Intl. J. Agric. Crop Sci., 7 (9): 532-536. 
Le-Doct, A. (1927). Commercial determination of sugar in beet root using the Sackes-Le-Doct Process. Int. Sug. J., (29): 488-492.

Ossom E. M. and R. L. Rhykerd (2007). Response of Ipomoea batatas (L.) Lam. to soil fertilization with filter cake. Transactions of the Illinois State Academy of Science, vol. 100, no. 3-4, pp. 197208.

Ossom, E. M. (2010). Effects of filter cake fertilization on weed infestation, disease incidence and tuber yield of cassava (Manihot 152 nta) in Swaziland. International Journal of Agriculture and עivevgy, vol. 12, no. 1, pp. 45-50.

Ossom E. M. and F. T. Dlamini (2012). Effects of filter cake on soil mineral nutrients and maize (Zea mays L.) agronomy. Tropical Agriculture, vol. 89, no. 3, pp. 141-150.

Pessarakli, M. (2010). Handbook of Plant and Crop Stress. Third Edition. CRC Press.

Qadir, M. S.; Schubert, A. D.; Noble, M. Saqib and Saifulla,H. (2006). Amelioration strategies for salinity- induced land degradation. CAB Reviews: Perspectives in Agric., Veterinary Sci., Nutrition and Natural Resources 1, No. 069.

Reinefield, E., A.E.M. Merich, G. Baumgarten, C. Winner and U. Besis. (1974). Zur Voraussage des melassezyu cherus aus Ru beanalysen. In: D. A. Cooke and R. K. Scott, editors, The Sugar beet Crop. Chapman and Hall (World Crop Series), London, U.K.

Rymar', V.T., Mukhina, S.V., Agafonov, D.N., Skrebnev, V.N. and V.VAvdeeva (2003). Effect of fertilization on yield and quality of barley. Kormoproizvodstvo (10):14-16.

Salami, M. and S. Saadat (2013). Study of potassium and nitrogen fertilizer levels on the yield of sugar beet in jolge cultivar. J. Nov. Appl Sci., 2(4): 94-100.

Santana C. T. C., A. Santi, R. Dallacort, M. L. Santos, and C. B. Menezes (2012). Desempenho de cultivares de alface americana em resposta a diferentes doses de torta de filtro," Revista Ciência Agronômica, vol. 43, no. 1, pp. 22-29. 
Santos D. H., M. A. Silva, C. S. Tiritan, J. S. S. Foloni, and F. R. Echer (2011). Qualidade tecnológica da cana-de-açúcar sob adubação com torta de filtro enriquecida com fosfato solúvel," Revista Brasileira de Engenharia Agrícola e Ambiental, vol. 15, no. 5, pp. 443-449.

Shaheen, S. M., Shams, M. S., Khalifa, M. R., El-Dali, M. A., and J, Rinklebe (2017). Various soil amendments and environmental wastes affect the (im)mobilization and phytoavailability of potentially toxic elements in a sewage effluent 153 :d sandy soil. Ecotoxicology and Environmental Safety; 142:375-387.

Tan, K. H. (2003). Humic Matter in Soil and Environment, Principles and Controversies. Marcel Dekker, Inc., Madison, New York.

Utami S. R., S. Kurniawan, B. Situmorang, and N. D. Rositasari (2012). Increasing $P$-availability and $P$-uptake using sugarcane filter cake and rice husk ash to improve chinesse cabbage (Brassica Sp) growth in Andisol, East Java," Journal of Agricultural Science, vol. 4, no. 10, pp. 153-160.

Wu, G. Q., Q. Z.Shui, C. M. Wang, J. L. Zhang, H. J. Yuan, S. .J. .Li and Z. J. Liu (2015). Characteristics of $\mathrm{Na}^{+}$uptake in sugar beet (Beta vulgaris L) seedling under mild salt conditions. Acta physiol. Plants 37(4): 1-13.

Zaki, N., M. Amal, G. Ahmed, M.S. Hassanein and M. M. Tawfik (2012). Foliar application of potassium to mitigate the adverse impact of salinity on some sugar beet varieties.1: effect on growth and some physiological aspects. J. Appl. Sci. Res., 8(8): 4405-4416.

Zaki, N. M., M. S. Hassanein, Amal, G. Ahmed, Ebtsam, A. ElHousini and M. M. Tawfik (2014). Foliar Application of potassium to mitigate the adverse impact of salinity on some sugar beet varieties.2: Effect on yield and quality. Middle East J. Agr. Res., 3(3): 448-460. 


$$
\text { الملخص العربي }
$$

تأثنير إضافة محسنات التربة على جودة العصير ومحصول السكر في بنجر السكر تحت ظروف الار اضي الملحية

محسن عبد المنعم جامع 1، رمضان إسماعيل كناني، يحيي يوسف إبر اهيم درويش3، فكري

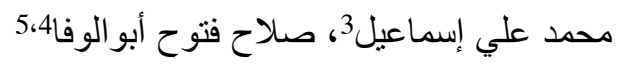

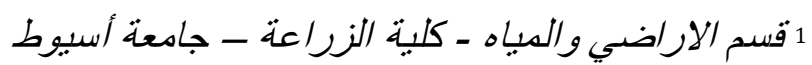

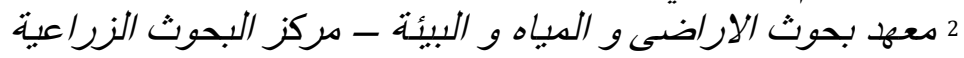

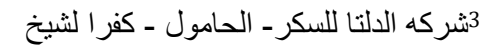

$$
\begin{aligned}
& 4 \text { كلية تكنولوجيا صناعة السكر والصناعات التكاملية - جامعة أسبوط النيوط }
\end{aligned}
$$

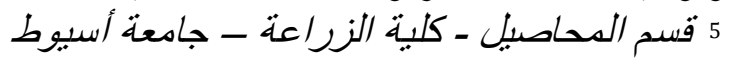

أجريت تجربة حقلية بالمزرعة البحثية لثركة الالتا للسكر، مصنع الحامول -

محافظه كفر الثيخ خلال الموسمين 2018/2017 و 2019/2018 باستخدم تصميم القطع المنشقة في أربعة مكررات. كان الههف من هذه الدراسة هو تقييم بعض

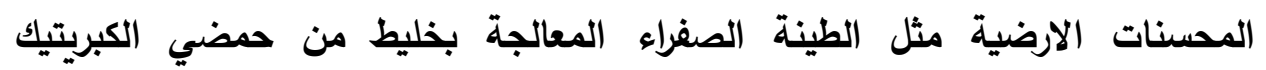
والفففوريك و فوسفوجيبسيم وحمض الهيوميك وكذلك مركب دي سال (مركب تجاري) علي جودة العصير ومحصول السكر في بنجر السكر تحت ظروف الأراضي الملحية. شغلت القطع الرئيسية بستة محسنات تربة: تم استخدام الطينة الصفراء المعالجة بمعدل 1 و2 طن للفدان، فوسفوجيبسيم، بمعدل 1 طن للفدان، دي سال 4 بمعدل لتر للفدان، حمض الهيومك بمعدل 4 لتر للفدان. و شغلت القطع المنشقة بثلاتة معدلات للمولاس هي بدون مولاس، 25 لتر مولاس للفدان، 50 لتر مولاس للفدان.

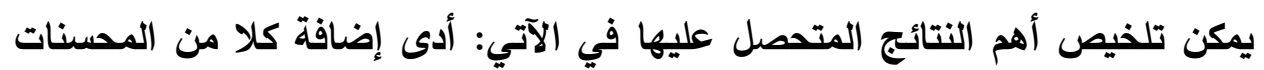
الارضية أو الملاس الى إنخفاض محتوى الثوائب (الصوديوم والبوتاسيوم والالفا أمينو

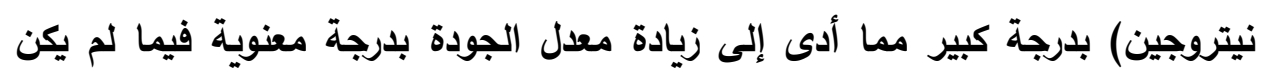

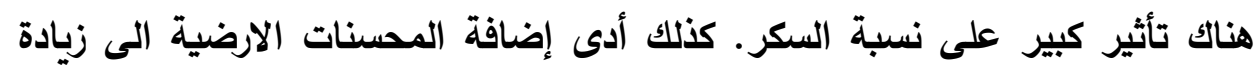
معنوية في محصول السكر ـ كان للطينة الصفراء المعالجة بخليط من حمضي الكبريتيك والفففوريك أثر كبير مقارنة بالمحسنات الاخرى في خفض محتوى الشوائب في عصير 
البنجر وتحسين جودة العصير ورفع محصول السكر، حيث أدى اضافة الطينة الصفراء

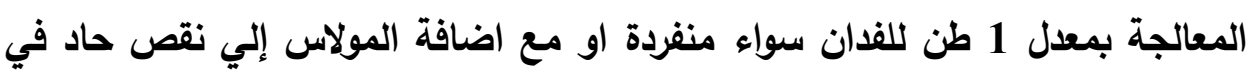
محتوى الشوائب وزيادة كبير في جودة العصير وكذلك محصول السكر . في حين لم يكن هناك تاثير يأكر للمحسنات الارضية على فاقد السكر مقارنة مع معاملات المقارنة.

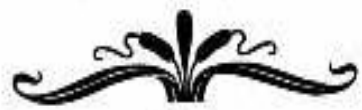

